\title{
Changes of Chemical Soil Characteristics by Dolomite and Bokashi Treatment and The Impact of Soybean (Glycine max L.) Production
}

\author{
Dahlan \\ Sekolah Tinggi Penyuluhan \\ Pertanian \\ Gowa, Indonesia
}

\author{
Kaharuddin \\ Sekolah Tinggi Penyuluhan \\ Pertanian \\ Gowa, Indonesia
}

\author{
Faisal Hamzah \\ Sekolah Tinggi Penyuluhan \\ Pertanian \\ Gowa, Indonesia
}

\author{
Nur Anny S. Taufieq \\ Universitas Negeri Makassar \\ Makassar, Indonesia
}

\begin{abstract}
Alfisol soil is one type of soil in Indonesia with widespread use and commonly cultivated for the development of soybean, especially in Sumatra, Java and Sulawesi island with constraints is soil $\mathbf{p H}$ is acidic, and soil fertility is low. Thus, it is necessary to put an input to improve chemical characteristics and productivity of soil. The research aimed to determine the effect of dolomite and bokashi of rice straw enriched filter cake to changes of soil chemical characteristics and on soybean production. This research was arranged according to randomized block design in two factorial, the first factor is the application of dolomite [ 0 t.ha1 (K0), 3 t.ha-1 (K1), 6 t.ha-1 (K2), 9 t.ha-1 (K3), and 12 t.ha-1 (K4)] and bokashi of rice straw enriched filter cake (SF) as a second factor [0 t.ha-1 (J0), 2 t.ha-1 (J1), 4 t.ha-1 (J2), 6 t.ha-1 (J3), and 8 t.ha-1 (J4)]. It obtained 25 combined treatment, with three replications. Parameters were measured, were: soil pH, Corganic, total $\mathrm{N}$, exchangeable cation capacity (CEC), and base saturation percentage (BSP) and soybean production. The data were analyzed using analysis of variance followed by Duncan's Multiple Range Test (DMRT) $\alpha 0.05$. The result of research revealed that Dolomite with 12 t.ha-1 dosage and bokashi of SF with 8 t.ha-1 have the best results to changes in soil chemical characteristics and on soybean production. Moreover, there is an interaction between the Dolomite and bokashi of SF to changes of soil chemical characteristics and on soybean production.
\end{abstract}

Keywords—chemical soil characteristics; Alfisol; dolomite; soybean

\section{INTRODUCTION}

Alfisol is one of kind of soil type in Indonesia with widespread use and commonly cultivated for soybean development, especially in Sumatera, Jawa and Sulawesi island with constraints are soil $\mathrm{pH}$ is acidic, and soil fertility is low, so it is necessary to put an input to improve chemical characteristics and productivity. One of the efforts to improving soil quality of Alfisol is liming and organic matter applying. Soybean is one of main food crops whose needs are constantly increasing, which is marked by the increasing imports of soybeans from year to year until now $60-65 \%$ of the national soybean needs, which reached 2.2 million tons per year met from imports. Anticipating this, the government is seeking an increase in soybean production through the expansion of planted area and increased productivity. Also, applying of soil conditioner is expected to improve soil chemical characteristics, and can enhance of fertilizing efficiency. Soil conditioner is often used is dolomite $(\mathrm{CaMg}(\mathrm{CO} 3) 2)$. Dolomite is a compound of $\mathrm{Ca}$ and $\mathrm{Mg}$ both can neutralize soil acidity and reduce the activity of the $\mathrm{H}$ and $\mathrm{Al}$ in the soil solution [1].

The adding of organic matter to the soil is critical because it is used as a nutrient source, it can also improve the physical, chemical, and biological soil characteristic. Utilization of rice straw and the filter cake is processed into bokashi is a combination of organic fertilizers which have a high nutrient content. The filter cake is a sugarcane industry waste having nutrient required by plants. The research aimed to determine the effect of dolomite and bokashi rice straw enriched filter cake to changes in soil chemical characteristics and on production of soybean.

\section{RESEARCH METHOD}

The research was conducted at the experimental farm STPP Gowa from April until November 2016, with the type of soil is Alfisol. This research was arranged according to randomized block design in two factorial, the first factor is application of dolomite [0 t.ha-1 (K0), 3 t.ha-1 (K1), 6 t.ha-1 (K2), 9 t.ha-1 (K3), and 12 t.ha-1 (K4)] and bokashi of rice straw enriched filter cake (SF) as second factor [0 t.ha-1 (J0), 2 t.ha-1 (J1), 4 t.ha-1 (J2), 6 t.ha-1 (J3), and 8 t.ha-1 (J4)], with three replications.

Liming and applying of bokashi SF are done about two weeks before planting. Planting is done with a drilling system with planting distance $40 \times 15 \mathrm{~cm}$. Maintenance performed include: watering, weeding and pest control. Parameters were measured, were: soil $\mathrm{pH}, \mathrm{C}$-organic, total $\mathrm{N}$, cation exchange capacity (CEC), and base saturation percentage (BSP) and soybean production. The data were analyzed using analysis of variance followed by Duncan's Multiple Range Test $\alpha 0.05$.

\section{RESUlTS AND DISCUSSION}

The result of DMRT $\alpha 0.05$ for soil characteristics ( $\mathrm{pH}, \mathrm{C}$ organic content, soil N-content, soil CEC and base saturation percentage sequentially shown in Table 1, Table 2, Table 3, Table 4 and Table 5. While Table 6 illustrates the effect of dolomite $(\mathrm{K})$ and bokashi of SF (J) on samples production plant. 
TABLE I. EFFECT OF DOLOMITE (K) AND BOKASHI OF SF (J) ON SOIL PH

\begin{tabular}{|c|c|c|c|c|c|c|}
\hline $\begin{array}{c}\text { Treatme } \\
\text { nts }\end{array}$ & J0 & J1 & J2 & J3 & J4 & $\begin{array}{c}\text { Avera } \\
\text { ge }\end{array}$ \\
\hline K0 & 5.05 & 5.05 & 5.15 & 5.05 & 5.05 & $5.07_{\mathrm{a}}$ \\
K1 & 5.15 & 5.10 & 5.10 & 5.10 & 5.10 & $5.11_{\mathrm{a}}$ \\
K2 & 5.10 & 5.25 & 5.15 & 5.15 & 5.10 & $5.15_{\mathrm{a}}$ \\
K3 & 5.30 & 5.25 & 5.40 & 5.55 & 5.44 & $5.39_{\mathrm{b}}$ \\
K4 & 5.57 & 5.46 & 5.61 & 5.53 & 5.59 & $5.55_{\mathrm{c}}$ \\
\hline Average & $5.23_{\mathrm{a}}$ & $5.22_{\mathrm{a}}$ & $5.28_{\mathrm{a}}$ & $5.28_{\mathrm{a}}$ & $5.26_{\mathrm{a}}$ & \\
\hline
\end{tabular}

TABLE II. EFFECT OF DOLOMITE (K) AND BOKASHI OF SF (J) ON CORGANIC $(\%)$ CONTENT

\begin{tabular}{|c|c|c|c|c|c|c|}
\hline $\begin{array}{c}\text { Treatme } \\
\text { nts }\end{array}$ & J0 & J1 & J2 & J3 & J4 & $\begin{array}{c}\text { Avera } \\
\text { ge }\end{array}$ \\
\hline $\mathrm{K} 0$ & $2.10^{\mathrm{x}}{ }^{\mathrm{p}}$ & $2.76_{\mathrm{x}}{ }^{\mathrm{q}}$ & $3.04_{\mathrm{x}}{ }^{\mathrm{r}}$ & $2.62_{\mathrm{x}}{ }^{\mathrm{q}}$ & $3.05_{\mathrm{x}}{ }^{\mathrm{r}}$ & $2.71_{\mathrm{a}}$ \\
$\mathrm{K} 1$ & $3.42_{\mathrm{xy}}{ }^{\mathrm{p}}$ & $3.36_{\mathrm{xy}}{ }^{\mathrm{p}}$ & $3.33_{\mathrm{xy}}{ }^{\mathrm{p}}$ & $3.40_{\mathrm{y}}{ }^{\mathrm{p}}$ & $3.42_{\mathrm{y}}{ }^{\mathrm{p}}$ & $3.39_{\mathrm{b}}$ \\
$\mathrm{K} 2$ & $3.52_{\mathrm{y}}{ }^{\mathrm{q}}$ & $3.07_{\mathrm{x}}{ }^{\mathrm{p}}$ & $3.12_{\mathrm{x}}{ }^{\mathrm{p}}$ & $3.25_{\mathrm{y}}{ }^{\mathrm{p}}$ & $3.36_{\mathrm{xy}}{ }^{\mathrm{p}}$ & $3.26_{\mathrm{b}}$ \\
$\mathrm{K} 3$ & $3.13_{\mathrm{x}}{ }^{\mathrm{p}}$ & $3.40_{\mathrm{y}}{ }^{\mathrm{p}}$ & $3.12_{\mathrm{x}}{ }^{\mathrm{p}}$ & $3.37_{\mathrm{y}}{ }^{\mathrm{p}}$ & $3.42_{\mathrm{y}}{ }^{\mathrm{p}}$ & $3.29_{\mathrm{b}}$ \\
$\mathrm{K} 4$ & $3.12_{\mathrm{x}}{ }^{\mathrm{p}}$ & $3.14_{\mathrm{xy}}{ }^{\mathrm{p}}$ & $3.42_{\mathrm{y}}{ }^{\mathrm{p}}$ & $3.28_{\mathrm{y}}{ }^{\mathrm{p}}$ & $3.24_{\mathrm{xy}}{ }^{\mathrm{p}}$ & $3.24_{\mathrm{b}}$ \\
\hline Average & $3.06_{\mathrm{a}}$ & $3.15_{\mathrm{ab}}$ & $3.21_{\mathrm{ab}}$ & $3.18_{\mathrm{ab}}$ & $3.30_{\mathrm{b}}$ & \\
\hline
\end{tabular}

TABLE III. EFFECT OF DOLOMITE (K) AND BOKASHI OF SF (J) ON SOIL N (\%) CONTENT

\begin{tabular}{|c|c|c|c|c|c|c|}
\hline $\begin{array}{c}\text { Treatme } \\
\text { nts }\end{array}$ & J0 & J1 & $\mathbf{J} 2$ & $\mathbf{J 3}$ & $\mathbf{J 4}$ & $\begin{array}{c}\text { Avera } \\
\text { ge }\end{array}$ \\
\hline $\mathrm{K} 0$ & $0.14_{\mathrm{x}}{ }^{\mathrm{pq}}$ & $0.14_{\mathrm{x}}{ }^{\mathrm{pq}}$ & $0.16_{\mathrm{x}}{ }^{\mathrm{q}}$ & $0.13_{\mathrm{x}}{ }^{\mathrm{p}}$ & $0.18_{\mathrm{x}}{ }^{\mathrm{r}}$ & $0.15_{\mathrm{a}}$ \\
$\mathrm{K} 1$ & $0.2{1_{\mathrm{yz}}}^{\mathrm{p}}$ & $0.25_{\mathrm{yz}}{ }^{\mathrm{q}}$ & $0.24_{\mathrm{yz}}{ }^{\mathrm{q}}$ & $0.20_{\mathrm{y}}{ }^{\mathrm{p}}$ & $0.24_{\mathrm{y}}{ }^{\mathrm{q}}$ & $0.22_{\mathrm{b}}$ \\
$\mathrm{K} 2$ & $0.22_{\mathrm{yz}}$ & $0.24_{\mathrm{yz}}{ }^{\mathrm{q}}$ & $0.23_{\mathrm{y}}{ }^{\mathrm{pq}}$ & $0.21_{\mathrm{yz}}{ }^{\mathrm{p}}$ & $0.24_{\mathrm{y}}{ }^{\mathrm{q}}$ & $0.23_{\mathrm{b}}$ \\
$\mathrm{K} 3$ & $\mathrm{pq}^{\mathrm{p}}$ & $0.26_{\mathrm{z}}{ }^{\mathrm{r}}$ & $0.23_{\mathrm{y}}{ }^{\mathrm{q}}$ & $0.23_{\mathrm{z}}{ }^{\mathrm{q}}$ & $0.24_{\mathrm{y}}{ }^{\mathrm{qr}}$ & $0.23_{\mathrm{b}}$ \\
$\mathrm{K} 4$ & $0.20_{\mathrm{y}}{ }^{\mathrm{p}}$ & $0.23_{\mathrm{y}}{ }^{\mathrm{p}}$ & $0.26_{\mathrm{z}}{ }^{\mathrm{q}}$ & $0.27_{\mathrm{n}}{ }^{\mathrm{q}}$ & $0.28_{\mathrm{z}}{ }^{\mathrm{q}}$ & $0.25_{\mathrm{c}}$ \\
& $0.23_{\mathrm{z}}{ }^{\mathrm{p}}$ & & & & & \\
\hline Average & $0.20_{\mathrm{a}}$ & $0.22_{\mathrm{bc}}$ & $0.22_{\mathrm{b}}$ & $0.21_{\mathrm{a}}$ & $0.24_{\mathrm{c}}$ & \\
\hline
\end{tabular}

TABLE IV. EFFECT OF DOLOMITE (K) AND BOKASHI OF SF (J) ON SOIL $\operatorname{CEC}\left(\operatorname{CMOL}(+) \mathrm{KG}^{-1}\right)$

\begin{tabular}{|c|c|c|c|c|c|c|}
\hline $\begin{array}{c}\text { Treatme } \\
\text { nts }\end{array}$ & J0 & J1 & J2 & J3 & J4 & $\begin{array}{c}\text { Avera } \\
\text { ge }\end{array}$ \\
\hline K0 & $22.04_{\mathrm{y}}{ }^{\mathrm{q}}$ & $19.90_{\mathrm{x}}{ }^{\mathrm{p}}$ & $18.86_{\mathrm{x}}{ }^{\mathrm{p}}$ & $20.38_{\mathrm{x}}{ }^{\mathrm{p}}$ & $20.30_{\mathrm{x}}{ }^{\mathrm{p}}$ & $20.30_{\mathrm{a}}$ \\
$\mathrm{K} 1$ & $18.63_{\mathrm{x}}{ }^{\mathrm{p}}$ & $22.92_{\mathrm{y}}{ }^{\mathrm{p}}$ & $24.82_{\mathrm{z}}{ }^{\mathrm{s}}$ & $24.22_{\mathrm{y}}$ & $21.34_{\mathrm{x}}{ }^{\mathrm{q}}$ & $23.33_{\mathrm{b}}$ \\
$\mathrm{K} 2$ & $22.66_{\mathrm{y}}{ }^{\mathrm{p}}$ & $22.09_{\mathrm{y}}{ }^{\mathrm{p}}$ & $21.27_{\mathrm{y}}{ }^{\mathrm{p}}$ & ${ }^{\mathrm{rs}}$ & $24.70_{\mathrm{y}}{ }^{\mathrm{q}}$ & $33.03_{\mathrm{b}}$ \\
$\mathrm{K} 3$ & $25.96_{\mathrm{z}}{ }^{\mathrm{q}}$ & $25.32_{\mathrm{z}}{ }^{\mathrm{q}}$ & $21.32_{\mathrm{y}}{ }^{\mathrm{p}}$ & $24.41_{\mathrm{y}}{ }^{\mathrm{q}}$ & $25.45_{\mathrm{y}}{ }^{\mathrm{q}}$ & $24.68_{\mathrm{c}}$ \\
$\mathrm{K} 4$ & $25.96_{\mathrm{z}}{ }^{\mathrm{p}}$ & $26.25_{\mathrm{z}}{ }^{\mathrm{p}}$ & $25.95_{\mathrm{z}}{ }^{\mathrm{p}}$ & $\begin{array}{c}25.36_{\mathrm{yz}} \\
\mathrm{q}\end{array}$ & $25.41_{\mathrm{y}}{ }^{\mathrm{p}}$ & $26.05_{\mathrm{d}}$ \\
& & & & & & \\
& & & & $26.52_{\mathrm{z}}{ }^{\mathrm{p}}$ & & \\
\hline Average & $24.16_{\mathrm{ab}}$ & $23.30_{\mathrm{bc}}$ & $22.44_{\mathrm{a}}$ & $24.18_{\mathrm{c}}$ & $23.44_{\mathrm{bc}}$ & \\
\hline
\end{tabular}

TABLE V. EFFECT OF DOLOMITE (K) AND BOKASHI OF SF (J) ON SOIL $\operatorname{BSP}(\%)$

\begin{tabular}{|c|c|c|c|c|c|c|}
\hline $\begin{array}{c}\text { Treatme } \\
\text { nts }\end{array}$ & J0 & J1 & J2 & J3 & J4 & $\begin{array}{c}\text { Avera } \\
\text { ge }\end{array}$ \\
\hline K0 & $33.00_{x y}$ & $32.00^{p}$ & $36.50_{x}{ }^{q}$ & $35.00^{p}{ }^{p}$ & $34.00_{\mathrm{x}}^{\mathrm{p}}$ & $34.10_{\mathrm{a}}$ \\
\hline K1 & $\mathrm{p}$ & $39.500^{r}$ & $34.50_{x}{ }^{q}$ & $36.00^{\mathrm{q}}{ }^{\mathrm{q}}$ & $43.50_{\mathrm{y}}{ }^{\mathrm{s}}$ & $36.70_{\mathrm{b}}$ \\
\hline $\mathrm{K} 2$ & $30.00^{p}{ }^{p}$ & $53.50_{\mathrm{n}}{ }^{\mathrm{s}}$ & $48.50_{y}{ }^{r}$ & $47.50_{z}{ }^{r}$ & $44.00_{\mathrm{yz}}$ & $45.30_{\mathrm{e}}$ \\
\hline K3 & $33.00_{x y}$ & $46.00_{z}{ }^{r}$ & $52.00_{\mathrm{z}}^{\mathrm{s}}$ & $40.00_{\mathrm{y}}{ }^{\mathrm{q}}$ & $\mathrm{q}$ & $43.20_{d}$ \\
\hline \multirow[t]{3}{*}{ K4 } & $\mathrm{p}$ & $38.00_{\mathrm{y}}{ }^{\mathrm{q}}$ & $36.50_{x}$ & $45.00_{\mathrm{z}}{ }^{\mathrm{r}}$ & $42.00_{\mathrm{y}}{ }^{\mathrm{q}}$ & $40.00_{c}$ \\
\hline & $36.00_{y}{ }^{p}$ & & $\mathrm{pq}$ & & $47.00_{\mathrm{z}}{ }^{\mathrm{r}}$ & \\
\hline & $\begin{array}{c}33.50_{\mathrm{xy}} \\
\mathrm{p}\end{array}$ & & & & & \\
\hline Average & $33.10_{\mathrm{a}}$ & $41,80_{b}$ & $41.60_{\mathrm{b}}$ & $40.70_{b}$ & $42.10_{\mathrm{b}}$ & \\
\hline
\end{tabular}

TABLE VI. EFFECT OF DOLOMITE (K) AND BOKASHI OF SF (J) ON SOYBEAN PRODUCTION (G)

\begin{tabular}{|c|c|c|c|c|c|c|}
\hline $\begin{array}{c}\text { Treatme } \\
\text { nts }\end{array}$ & $\mathbf{J 0}$ & $\mathbf{J 1}$ & $\mathbf{J 2}$ & $\mathbf{J 3}$ & $\mathbf{J 4}$ & $\begin{array}{c}\text { Avera } \\
\text { ge }\end{array}$ \\
\hline $\mathrm{K} 0$ & $18.58_{\mathrm{x}}{ }^{\mathrm{p}}$ & $20.24_{\mathrm{x}}{ }^{\mathrm{q}}$ & $21.05_{\mathrm{x}}{ }^{\mathrm{r}}$ & $28.22_{\mathrm{x}}{ }^{\mathrm{s}}$ & $33.22_{\mathrm{n}}{ }^{\mathrm{t}}$ & $24.26_{\mathrm{a}}$ \\
$\mathrm{K} 1$ & $20.29_{\mathrm{y}}{ }^{\mathrm{p}}$ & $23.86_{\mathrm{y}}{ }^{\mathrm{q}}$ & $28.44_{\mathrm{y}}{ }^{\mathrm{r}}$ & $28.76_{\mathrm{y}}{ }^{\mathrm{s}}$ & $28.87_{\mathrm{x}}{ }^{\mathrm{t}}$ & $26.04_{\mathrm{b}}$ \\
$\mathrm{K} 2$ & $20.80_{\mathrm{z}}{ }^{\mathrm{p}}$ & $28.21_{\mathrm{z}}{ }^{\mathrm{q}}$ & $28.34_{\mathrm{z}}{ }^{\mathrm{r}}$ & $29.67_{\mathrm{z}}{ }^{\mathrm{s}}$ & $32.10_{\mathrm{y}}{ }^{\mathrm{t}}$ & $27.82_{\mathrm{c}}$ \\
$\mathrm{K} 3$ & $22.11_{\mathrm{n}}{ }^{\mathrm{p}}$ & $28.33_{\mathrm{n}}{ }^{\mathrm{q}}$ & $29.33_{\mathrm{n}}{ }^{\mathrm{r}}$ & $31.93_{\mathrm{n}}{ }^{ }$ & $33.07_{\mathrm{z}}{ }^{\mathrm{t}}$ & $28.95_{\mathrm{c}}$ \\
$\mathrm{K} 4$ & $30.12_{\mathrm{o}}{ }^{\mathrm{p}}$ & $30.60_{\mathrm{o}}{ }^{\mathrm{q}}$ & $31.86_{\mathrm{o}}{ }^{\mathrm{r}}$ & $33.67_{\mathrm{o}}{ }^{\mathrm{s}}$ & $36.85_{\mathrm{o}}{ }^{\mathrm{t}}$ & $32.62_{\mathrm{d}}$ \\
\hline Average & $22.38_{\mathrm{a}}$ & $26.25_{\mathrm{b}}$ & $27.80_{\mathrm{b}}$ & $30.45_{\mathrm{c}}$ & $32.82_{\mathrm{d}}$ & \\
\hline
\end{tabular}

The result of DMRT $\alpha 0.05$ for $\mathrm{pH}$ showed in Table 1. (K), K4 (Dolomite factor) have highest results (5.55) and have a significant difference from other treatments. While, bokashi of SF (J), J2 treatment has the highest result (5.61) and have not a significant difference with other treatments. The C-organic showed in Table 2. K1 treatment as Dolomite has highest results $(3.39 \%)$, and only have a significant difference with K0. While, BSFC (J), J4 have the highest results (3.30\%), and only have a significant difference with $\mathrm{K} 0$.

Effect dolomite and bokashi to the $\mathrm{N}$ content of soil showed in Table 3. Treatment K4 have the highest result $(0.25 \%)$ and significant difference from other treatments. While, bokashi of SF (J), J4 has the highest result $(0.24 \%)$ and have a significant difference with other treatments. CEC soil by the research treatment shows in Table 4 that for dolomite (K) K4 have the highest results $(26.05 \mathrm{mmol}(+) \mathrm{kg}-1)$ and have a significant difference with other treatments. While, bokashi of bokashi of SF (J), J3 have the highest results (24.18 mmol(+)kg-1), although have not a significant difference with $\mathrm{J} 1$ and $\mathrm{J} 4$. Table 5 shows that for Dolomite $(\mathrm{K}), \mathrm{K} 2$ have the highest results $(45.30 \%)$ and have a significant difference with other treatments. While, bokashi of SF (J), J4 have the highest yield $(42.10 \%)$, although only have not a significant difference with J0.

Plant production showed in Table 6 that for Dolomite $(\mathrm{K})$ $\mathrm{K} 4$ have the highest results $(32.62 \%)$ and have a significant difference with other treatments. While, bokashi of SF (J), J4 have the highest yield $(42.10 \%)$, have an important difference with other treatments. The results showed that applying of dolomite have a positive effect, that is can to increase the value of soil $\mathrm{Ph}$. The increasing $\mathrm{pH}$ value caused by the process and the reaction of lime in the soil which is most effected by the availability of water in the soil [2].

For the content of C-organic and total N, dolomite, and bokashi of SF, and their interaction has a positive effect on Total $\mathrm{N}$ and $\mathrm{C}$-organic. The existence of high significant effect on the C-organic and $\mathrm{N}$ from dolomite lime caused the applying of dolomite could be able to increase the activity of microbial decomposers of soil organic matter [3]. Increasing of C-organic and $\mathrm{N}$ content is also affected on decomposers. Using organic matter change the physicochemical and biological soil characteristics [4].

The results showed that dolomite treatment and bokashi of $\mathrm{SF}$, and their interactions have a highly significant effect on production. With the increase of $\mathrm{pH}$ value, the nutrient in the soil was expected to be available for plant growth. If $\mathrm{pH}$ is 
neutral, then almost all nutrients required by plants for growth in the available [5].

\section{CONCLUSION}

Dolomite with 12 t.ha-1 and bokashi of SF with 8 t.ha-1 have the best results to changes in soil chemical characteristics and on plant production. Their interaction between the dolomite and bokashi of rice straw enriched filter cake to changes in soil chemical characteristics and on plant production.

\section{REFERENCES}

[1] L. Devi, K. J. Ptasinski, F. J. J. G. Janssen, S. V. B. van Paasen, P. C. A. Bergman, and J. H. A. Kiel, "Catalytic decomposition of biomass tars: use of dolomite and untreated olivine," Renew. energy, vol. 30, no. 4, pp. 565-587, 2005.

[2] E. L. De Oliveira and M. A. Pavan, "Control of soil acidity in the notillage system for soybean production," Soil Tillage Res., vol. 38, no. 12, pp. 47-57, 1996.

[3] D. W. Nelson and L. E. Sommers, "Total carbon, organic carbon, and organic matter," Methods soil Anal. part 3-chemical methods, no. methodsofsoilan3, pp. 961-1010, 1996.

[4] K. Bouajila and M. Sanaa, "Effects of organic amendments on soil physicochemical and biological properties," J. Mater. Environ. Sci, vol. 2, no. 1, pp. 485-490, 2011.

[5] A. Suksri, "Effects of dolomite on growth and seed yields of soybeans (Glycine max L.) grown on oxic paleustult soil in Northeast Thailand," Pak. J. Biol. Sci, vol. 1, no. 21, pp. 5-218, 1998. 